\title{
Yezid b. Abdüilmelik ve Dönemi Üzerine
}

\author{
M. AKIF FIDAN
}

DR.

\section{abstract}

Yezid B. Abdulmelik and His Term. Yezid b. Abdülmelik is the 9th Khalifa of the Emevi dynasty after Ömer b. Abdülaziz. His term of power is between the years 720-724. He became heir to the throne with the legacy of his father, Abdülmelik b. Mervan (5th Emevi Khalifa), but many people did not see him appropriate to the crown. There are too many negative commitments about his administration and personality while there are very few positive ones. He followed peaceful and neutral politics of Ömer b. Abdulaziz in the domestic politics for a short time, but then he gave up. Domestic conflicts were again flamed because of his sided administration; this situation clearly became one of the reasons of the collapse of Emevi dynasty. During his term of power, he was criticized as being too much interested in entertainment, poetry and music and as not giving enough importance to the state administration. There was an attempt to coup d'etat against him. Although he governed the country with daily simple actions, the claims that he fully left the state administration due to the entertainment are really wrong. Negative applications against Christians, taxing again non-Arab Muslims, hostile attitudes against Mühellebiler family who served devotedly to the Emevi State from the beginning are such applications to which many people negatively reacted. In foreign policy, he did not have his own line, he followed traditional conquest policy. In the time of Yezid, beside several defeats, he got some small successes. He died in 105/724.

key words

Emevi Dynasty, Ömer b. Abdulaziz, Abdülmelik b. Mervan, Islamic History.

\section{A. HAYATI}

Nesebi ve Doğumu: Yezid b. Abdülmelik Ümeyyeoğulları hanedanlığının dokuzuncu Halifesidir. Babası, Emevî hanedanının beşinci devlet başkanı olan ve Emevî Devleti'ni derleyip toparladı̆̆ı için ikinci kurucusu sayılan, Halife Abdülmelik b. Mervan idi ${ }^{1}$. Annesi ise Atike b. Yezid b. Muaviye'dir. I.Yezid olarak bilinen Emevî devletinin ikinci Halifesi, Yezid b. Muaviye b. Ebî Süfyan'ın (60-64/680-684) kızıdır. Yezid b. Abdülmelik hem annesi, hem babası Ümeyyeoğullarının soylu kabul edilen ailelerinden gelmektedir. Yezid b. Abdülmelik II. Yezid olarak tanınır. Çünkü² anneden dedesi, Yezid b. Muavi-

1 Geniş bilgi için bkz. Erkoçoğlu, Fatih, Abdülmelik b. Mervân ve Dönemi (65-86/685-705), Ankara Üniversitesi Sosyal Bilimler Enstitüsü, Basılmamış Doktora Tezi, Ankara 2006.

2 İbn Habib, Ebû Cafer Muhammed İbni Ümeyye b. Amru, Kitabü'l-Muhabber, (thk. Eliza Lichtenstater, Daira-tü'l-Meârifü'l-Osmaniye, Haydarabad 1942), 45; Erkoçoğlu, Abdülmelik, 72. 
ye I. Yezid olarak tanınır. Künyesi Ebû Halid olan Yezid b. Abdülmelik, annesinden dolayı Yezid b. Atike diye de bilinirdi. ${ }^{3}$

Temel kaynaklardan elde edilen sonuca göre, Yezid b. Abdülmelik büyük ihtimalle 71/691(veya 72/692) yılında Şam'da doğmuştur. Muaviye, Abdülmelik, Velid ve Hişam gibi, Emevîlerin diğer Halifelerine göre daha kısa süren Yezid b. Abdülmelik'in hilafet süresi, Miladi olarak 9 Şubat 720 ile 28 Ocak 724 tarihleri arasında üç yıl, on bir ay, yirmi bir gündür. Hicri takvime göre ise, 25 Recep 101 ile 26 Şaban 105 tarihleri arasında, dört yıl, bir ay, iki gün devlet başkanlığında bulunmuştur. ${ }^{4}$

Yetişmesi ve Eğlenceye Düşkünlüğü: Ömer b. Abdülaziz'in ölümünün ardından devlet başkanlığına geçen Yezid'in, hilafetine kadar ki hayatı hakkında yeterli bilgiye sahip değiliz. Ancak saray ortamında büyüdüğü, devlet başkanı olan babasından dolayı her istediğine ulaştığı, rahat ve bolluk içerisinde yetiştiği güçlü bir ihtimaldir. Yezid'in yetişmesiyle annesi Atike'nin yakından ilgilendiği kaynaklarımızdan anlaşılmaktadır. ${ }^{5}$

Yetiştiği bu saray ortamı nedeniyle olsa gerek, Yezid'in şahsiyetinde müziğe, şiire ve eğlenceye normalden fazla bir düşkünlük gözlemlenmiştir. Eğlence ve eğlence meclislerine aşırı düşkünlüğü ile bilinen Yezid'in ölümünün, şarkıcı cariyesinin ölüm acısına dayanamaması üzerine gerçekleştiği, birçok kaynağımızda yer almaktadır. ${ }^{6}$ Yezid, eğlenceye, oldukça fazla para harcamış, bu konuda çok müsrif davranmıştır. Henüz gençliğinde çok para vererek bir cariye alması, kardeşi Halife Velid b. Abdülmelik'in sert tepkisini çekmiştir. ${ }^{7}$ Yine, şiirini çok beğendiği bir şairin ağzının mücevherle doldurulması emrini vermesi, ${ }^{8}$ bu konuya başka bir örnektir.

3 Yıldız, D. Hakkı, "Yezid b. Abdülmelik", İ.A. Mad., (M.E.B. İslam Ansiklopedisi, Milli Eğitim Basımevi, I-XIII, İstanbul 1986), XIII, 409.

4 Tarihlerin Hicri/Miladi karşılıkları için bkz. Dağlı, Y., Üçer, C., Tarih Çevirme Kılavuzu, (T.T.K. Yay., Ankara 1997).

5 İsfehanî, Ebü'l-Ferec, Ali b. Hüseyin b. Muhammed, Kitabü’l-Eğanî, (thk. Ali Muhanna ve ark., Darü'l-Kütübü'l-i̇lmiye, I-XXIII, Beyrut 1992), II, 247; İbni Hamdun, Muhammed b. Hasan b. Ali, Tezkiretü'l-Hamduniyye, (thk. İhsan Abbas, I-X, Darü Sadr, Beyrut, 1996), II, 94.

6 Hayyat, Halife b. Hayyat, Ebû Amr, Tarihu Halife b. Hayyat, (thk. Süheyl Zekkar, Darü'l-Fikr, Beyrut 1993), 259; Belâzurî, Ebû'l-Hasan Ahmed b. Yahya b. Cabir, Kitabu Cümel Min Ensâbi'l-Eşraf, (thk. Süheyl Zekkar, Riyaz Zerkay, Darü'l-Fikr, I-XIII, Beyrut 1996),VIII, 243, 261, 267; Dineverî, Ebî Hanife Ahmed b. Davud, Ahbaru't-Tival, (Matbatü's-Seade, Misır 1330), 320; Yakubî, Ahmed b. Ebî Yakub b. Cafer b. Vehb, Tarihü’l-Yakubî, (Matbuat Gara, Necef tsz), II, 242; Taberî, Ebî Ca'fer Muhammed b. Cerîr, Tarihu'l-Ümem ve'l-Muluk, (thk. Muhammed Ebû'l-Fadl İbrahim, I-XI, 4. Bask., Darü'l-Meârif, Kahire 1990), VII, 21-25; İbni Abdirabbih, Ebî Ahmed el-Endelusî, el-Ikdü'l-Ferîd, (thk. Ahmed Emin ve ark. I-VII, 3. Bask., Matbatü Lecnetü't-Telif, Kahire 1965),IV, 444-445; Ezdi, Ebî Zekeriya Yezid b. Muhammed b. İyas b. El-Kasım, Tarihu'l-Mevsıl, (thk. Ali Habibe, Kahire 1967),18,20,21; Mes'udî, Ebîl'-Hasan Ali b. Hüseyin b. Ali, Murucu'z-Zeheb ve Medainü'l-Cevher, (thk Yusuf Esad Dağir, Darü'l-Endelüs, I-IV, , Beyrut 1965), III, 195-205.

7 İsfehanî, IV, 249.

8 İsfehanî, I, 355; Kutübî, Muhammed b. Şakir b. Ahmed b. Abdurrahman, Fevatü'l-Vefayat ve'z- 
Dini Duyarlılı̆̆ı: Yezid, İlk zamanlar kendinden önceki devlet başkanı, Emevilerin dindarlığıyla öne çıkmış halifesi Ömer b. Abdülaziz'in (99-101/ 717-720) yolundan gitmeye çalışmışsa da, bir süre sonra bundan vazgeçmiştir. İleri görüşlü kardeşi Mesleme b. Abdülmelik, eğlenceyle geçen günleri, kötü gidişatı ve devlet işlerinin aksamasını hatırlatarak Müslümanların Halifesine bu yaptıklarının yakışmadığı uyarısında bulunmuştu. Bu uyarı nedeniyle bir süre eğlenceye ara vermişse de, sonradan eski hayatına dönmüştür. ${ }^{9}$

Burada şunu belirtmeliyiz ki, elinde birçok imkânı bulunan, lüks içerisinde yaşayan her istediğini yapabilme potansiyeli olan bir insanı, bu tür eğlencelerden, dini duyarlılık dışında engelleyecek pek fazla etken yok gibiydi. Yezidin dini duyarlılığının ise nispeten zayıf olduğu bilinmektedir. Şöyleki kendinden önceki halifelerin aksine, halifelerin görevi olarak kabul edilen namazları kıldırmaya, kendisinin gitmeyip kardeşi Mesleme'yi göndermesi, dini duyarlılığına iyi bir örnek oluşturur. Ancak şunu da belirtelim ki; İbn Kesîr ve Zehebî kesin ifadelerle, Yezid b. Abdülmelik'in dini yönünün zayıf olduğu yönündeki iddiaların doğru olmadığını belirtmişlerdir. İbni Kesîr böyle olanın yine bir Halife olan oğlu II. Velid b. Yezid olduğunu da eklemiştir. ${ }^{10}$

İbn Kesîr ve Zehebî’nin ifade ettikleri dini yönünün zayıf olmadığı yönündeki görüşü destekleyen bilgileri, hilafetinden önceki döneme ait bazı haberlerden çıarmaktayız. Örneğin Halife olmadan önce Mekhul gibi dönemin saygın bir aliminin meclisine gittiği kayıtlıdır. ${ }^{11}$ Ayrıca, Ömer b. Abdülaziz'in gidişatına benzer bir tavır ile hilafetinin ilk günlerinde bütün namazlarını cemaatle kıldığını ancak sonradan bu halinin değiştiğini, hatta memnuniyetsizliklerinden dolayı, Kureyş'in ileri gelenlerinin Yezid'i görevden alma girişiminde bulundukları bildirilmektedir. ${ }^{12}$

Zeylü Aleyha, (thk. İhsan Abbas, Darü Sadr, , I-V, Beyrut 1973), IV, 201; Zeydan, Corci, Medeniyeti İslamiye Tarihi, (Terc. Zeki Megamiz, İstanbul 1328),V, 238.

9 Mes'udî, Muruc, 196; İbnü’l-İmad, İmam Şihabüddin Ebî'l-Felah Abdi'l-Hay b. Muhammed b. Ahmed b. Muhammed el-Akriyyi'l-Hanbeli ed-Dımeşki, Şezerâtü'z-Zeheb fi Abari Men Zeheb, (thk. Mahmud Arnavut, Darü İbni Kesîr, I-VI, Beyrut 1988), II, 29; İbn Hamdun, IX, 43; Nüveyrî, Şihebü'd-Din Ahmed b. Abdülvehab, Nihayetü'l-Ereb fi Fünuni'l-Edeb, (thk. Ali Muhammed Becavi Heyetü'l-Misriyye Amme Li'l-Küttab, , I-XXXI, Kahire 1986), XXI, 399-400; İbnü'lCevzî, Cemalüddin Ebîl'-Ferec Abdurrahman, el-Muntazam fi Tevarihi'l-Müluk ve'l-Ümem, (thk. Süheyl Zekkar, I-XIII, Darü'l-Fikr, Beyrut 1995), IV, 535-536; İsfehanî, XV, 125-130.

10 İbni Kesîr, İmamü'd-Din Ebü'l-Fida İsmail İbni Ömer, el-Bidaye ve'n-Nihaye fi't-Tarih, (Matbaatü's-Saade, Kahire 1932), IX, 232; Zehebî, Semsüddin Muhammed b. Ahmed b. Osman, Tarihu'l-İslam ve Vefayatü'l-Meşahir ve'l-A'lam, (thk. Ömer Abdusselam Tedmur'1, I-XLIV, Darü Kutübü'l-Arabi, Beyrut 1990),VI, 280.

11 Zehebî, Tarih, II, 279; Siyeru A'lami'n-Nübela, (thk. Şuayb Arnaut ve ark., I-XXV, 4. Bask., Müessesetü'r-Risale, Beyrut 1986), V, 150; Mes'udî, Muruc , III, 201; İbni Kesîr, IX, 232.

12 İbn Kuteybe, el-İmame ve's-Siyase, (thk. Muhammed ez-Zeyni, Müessesetü'l-Halebi Li'n-Neşr ve't-Tevzi', I-II, Kahire 1967), II,103; İbnü'l-Cevzî, IV, 535. 
Sonuç olarak hilafetinden önce dini duyarlılı̆̆ daha fazla olduğu anlaş1lan Yezid'in hilafete geçmesinin ardından, bulunduğu ortamın etkisiyle olsa gerek, dini gerekliliklerini aksattığı anlaşılıyor. Her ne kadar Yezid de, diğer Emevî Devlet Başkanları gibi dine karşı şahsi ilgisizliğinden dolayı eleştirilmişse de, temelde bütün Halifelerin İslâm'ın prensiplerini uygulanmasını istediklerini biliyoruz. ${ }^{13}$

Yezid'e yöneltilen eleştirilerden birisi de onun devlet idaresiyle ilgilenmediği, günlerini eğlenceyle geçirdiği iddiasıdır. Eğlenceye düşkünlüğü ve çok zaman ayırması ve düşkünlügüü onun devlet işlerinden tamamen uzak durduğu, idareyi tamamen valilere terk ettiği anlamına gelmeyeceği kanaatindeyiz. Nitekim devlet işlerindeki aksamalara rağmen idarede etkinliğini görüyoruz. Sık sık vali veya görevli atama ya da azillerinde bulunması buna bir örnek oluştururken, idareyle ilgilendiğinin en çarpıcı örneğini Hazarlarla savaşa gönderdiği ordunun komutanı Sübeyt'i, yenilgisi nedeniyle azarlaması ve yenilginin nedenini soruşturmasında görmekteyiz. ${ }^{14}$

Eşleri ve Çocukları: Kaynaklarımızdan Yezid b. Abdülmelik'in Arap geleneklerine uygun olarak, çok eşle evlendiğini öğrenmekteyiz. Bize ulaşan haberlerden anlaşıldığı üzere kardeşi Süleyman b. Abdülmelik döneminde (96-99/715-717) bu eşlerinden Abdullah b. Amr b. Osman b. Affan 'ın kızı Sa'de ve Muhammed b. Ali b. Abdullah b. Cafer'in kızı Rüveyda ile yirmişer bin dinar mehir vererek evlendi. ${ }^{15}$ Yezid devlet başkanı olmadan önce Hicaz'a gittiğinde kendisine gösterilen güzel bir şarkıcı olan Galiye'yi de dört bin dinar vererek almıştı. Devlet başkanı olan Süleyman buna kızmış, yapılan anlaşmayı iptal etmiştir. Eğlence meclislerinde ismine sıkça rastladığ1mız bu şarkıcıyı Yezid, Halife olduktan sonra, yeniden Cariye olarak almış ve ismini Habbâbe olarak değiştirmişti. ${ }^{16}$

13 Vaglari, Laura Veccia, İslam Tarihi Kültür ve Medeniyeti, Emevîler, (Bölm. Çev. İlhan Kutluer, I-IV, Hikmet Yay., İstanbul 1988), I, 89.

14 İbni A'sem el-Kufî, Ebû Muhammed Ahmed, el-Fütuh, (Darü'l-Kutübi'l-İlmiye, I-IV, Beyrut, 1986),IV, 260; İbnü'l-Esîr, Ebî'l-Hasan Ali b. Ebe'l-Kerem Muhammed b. Muhammed b. Abdülkerim b. Abdülvahid eş-Şeybani, el-Kamil fi't-Tarih, (thk. Muhammed b. Yusuf ed-Dahhâk, Darü'l-Kutübü'l-İlmiye, I-IX, Beyrut 1987),IV, 360; Nüveyrî, XXI, 381.

15 Belâzurî, Ensâb, VIII, 256; Taberî, VII,23; Ezdî, 20; Kutübî, IV, 323; Nüveyrî, XXI, 400; İsfehanî, $\mathrm{XV}, 121$; İsmi "Sa'de" diye veren bu kaynakların dışında "Ümmü Said" diye veren kaynaklarımız da vardır. İbn Habib, Muhabber, 243; İbni Hazm el-Endelusî, Ali b. Ahmed b. Said, Cemheratü Ensâbü'l-Arab, (Darü Kütübü İlmiye, Beyrut 1983), 85; İbnü'l-Cevzî, IV, 493; Kalkaşandî, Ahmed b. Ali, Subhu'l-Aş̧a fi Sinaati'l-İnşa, (thk. Muhammed Hüseyin Şemsüddin, Darü'l-Kütübü'l-İlmiye, I-XV, Beyrut 1987),I, 500; İbni Asakir ise "Mes'ade" olarak vermektedir. \{İbni Asakîr, Ebî'lKasım Ali b. Hasan İbni Hibetullah b. Abdullah eş-Şafîi, Tarihu Medinetü'd-Dımeșk, (thk. Ömer b. Ğarame el-Umri, Darü'l-Fikr, I-LX...., Beyrut 1995), XXXIII, 387\}.

16 Belâzurî, Ensâb, VIII, 256; Taberî, VII, 23; Ezdî, 20; Kutübî, Fevat, IV, 323; Nüveyrî, XXI, 400, İsfehanî, XV, 121. 
Yezidin değinmemiz gereken bir başka eşi de, kendisinden sonra veliaht bıraktığı oğlu II. Velid'in annesi Haccac'ın yeğeni olan Ümmü'l - Haccac'tır. Yezid'in yedisi cariyelerden olmak üzere toplam on üç çocuğu olmuştu. ${ }^{17}$

\section{B. HALIFE OLUŞU}

Emevî Devletinin 5. devlet başkanı Abdülmelik b. Mervan, kendinden sonra iki oğlu (Velid ve Süleyman)'nu veliahtlık mektubuyla Halife bırakmış, onlardan sonra da, hanımı Atîke'nin oğullarından hangisi hayatta kalırsa onun veliaht yapılmasını istemişti. Abdülmelik bunu uygulama görevini de ilk iki oğluna vermişti. Ancak Süleyman kendisinden sonra sarayda etkili bir din alimi olan Recâ b. Hayve'nin etkisiyle, ${ }^{18}$ yine dindarlığı ile öne çıkmış, adaletli uygulamaları nedeniyle II. Ömer diye bilinen, Ömer b. Abdülaziz'i veliaht tayin etmişti. ${ }^{19}$ Aile içerisinden gelebilecek tepkileri önlemek için de babası Abdülmelik'in tavsiyesine uyarak Ömer'den sonraya Abdülmelik'in Atîke'den oğlu, kardeşi Yezid'i Halife yapmıştır. ${ }^{20}$

Ümeyyeoğullarının menfaatleri doğrultusunda veliaht olan Yezid'i, Ömer b. Abdülaziz'in de, Haricîlerin de, Halife olarak görmek istemediklerini görüyoruz. Henüz Halife olmadan tepki alması, hilafete layık olmadığının dile getirilmesi ${ }^{21}$ dikkat çekicidir. Ömer b. Abdülaziz, Yezid'in Halife olacak olmasından rahatsızdı. Ancak ahde vefasından ve devlet içerisinde karışıklık çıkmasından çekindiği için herhangi bir girişiminde bulunmadı̆̆ını görüyoruz. $^{22}$

17 Bkz. İbni Zübeyr, Ebî Abdullah Mus'ab b. Abdullah b. Mus'ab, Kitabu Nesebû Kureyş, (nşr., Levi Provençal, 3. Bask., Darü'l-Meârif, Kahire 1982),166; Belâzuri, Ensâb, VIII, 351; İbni Kuteybe, Ebî Muhammed b. Abdullah b. Müslim, Kitabü'l-Meârif, (thk. Servet Ukkașe, 6. Bask., Hey'etü Mısriyye'l-Amme li'l-Küttab, Mısır 1992), 363; Yakubî, II, 242; İbni Abdirabbih,IV, 441;íbni Hazm el-Endulüsî, 91; İbni Asakir, XXII, 401; Nüveyrî, XXI, 402; Zehebî, Tarih, V, 152.

18 Ömer b. Abdulaziz'in halife seçilmesinde Recâ'nın rolü ile ilgili olarak ayrıca bkz. Erkoçoğlu, Fatih, "Recâ b. Hayve el-Kindî (Hayatı ve Faaliyetleri)", Cumhuriyet Üniversitesi İlahiyat Fakültesi Dergisi, Cilt XI/2, 2007, 383-397.

19 Recâ’nın Ömer b. Abdulaziz'in halife seçilmesindeki bu rolü nedeniyle olsa gerek ondan sonra halife olan Yezid, Recâ'ya mesafeli davranmıştır. bkz. Erkoçoğlu, "Recâ b. Hayve", 399.

20 İbni Sa'd, Muhammed, Ebû Abdullah, Tabakatü'l-Kübrâ, (Darü Sadr, I-IX, Beyrut 1990), V, 335; İbni Kuteybe, İmame, II, 67; Yakubî, II, 224; Taberî, VI, 413-417; İbni Abdirabbih, IV, 430; Mes'udî, Muruc, III, 183; İbnü'l-Esîr, IV, 324-325; İbni Kesîr, IX, 219, 231; Zehebî, Tarih, II, 279; A'lam, V, 150; Kalkaşandî, IX, 379; Suyutî, Abdurrahman b. Ebî Bekr, Tarihu'l-Hulefa, (thk. Muhammed Muhyiddin Abdulhamid, Mektebetü'l-Asriyye, Beyrut 1989), 258. Mektebetü'l-Asriyye, Beyrut 1989), 258; Erkoçoğlu, Abdülmelik, 249.

21 İbni Kuteybe, Imame, II, 99-100; İbni Abdirabbih, II, 400-402; Mes'udî, Muruc, III, 190-192; Hudari, Muhammed, Doğuştan Günümüze Büyük İslam Tarihi, Emevîler (edit: Hakkı Dursun Yıldız, İstanbul 1972),II, 516; Ahmet Cevdet, Kısas-ı Enbiya, (Haz. Mahir İz, 2. Bask., Kültür ve Turizm Bakanlığı Yay., Ankara 1985), IV, 77-78.

22 Muhammed Ebû Zehra, İslâm'da Fıkhi Mezhepler Tarihi, (Çev: A. Şener, Hisar Yay. İstanbul, 1978), 291. 
Emevî devletinin kurucusu Muaviye b. Ebû Süfyan tarafından saltanata dönüştürülen hilafet makamının, Yezid b. Abdülmelik'in bu makama atanması ile Ümeyyeoğullarının hilafeti kendi mülkleri olarak gördüklerinin başka bir örneği olmuştur. Yezid'in Halife olmasındaki temel neden, dikkat edilirse liyakati ya da Halifelerde aranan şartları taşımasından dolayı değildir. Abdülmelik'in, Atîke'den oğlu olmasıdır. Devlette Ümeyyeoğulları ve özellikle Kayslıların çıkarlarını koruyacağı beklentileri kanaatimizce, Yezid'in veliaht tayin edilmesindeki en güçlü ihtimaldir.

\section{VELIAHT TAYIN ETMESI}

Yezid b. Abdülmelik, Emevîlerde yerleşen geleneğe göre iki veliaht belirlemiştir. Kaynaklarımızın önemli bölümü Yezid'in, Süleyman döneminden beri Halifelik beklentisi olduğunu bildiğimiz kardeşi Hişam'ı kendisinden sonra, ondan sonra da, yaşı küçük olduğu için öncelik veremediği oğlu Velid b. Yezid'i veliaht belirlediğini kaydetmektedirler. ${ }^{23}$

\section{D. ÖLÜMÜ}

Yezid b. Abdülmelik'in ölümü hakkında, detaylardaki farklılıklar bir yana, kaynaklarımızın önemli bir bölümü, çok sevdiği Habbâbe ile köşkte insanlardan uzak, baş başa yiyip içip eğlendikleri sırada, Habbâbe'nin boğazına kaçan üzüm (yada nar) tanesiyle ölmesinin ardından, onun acısına dayanamayarak Yezid'in de öldüğüne işaret etmektedir.

Habbâbe'nin ölümünün ardından Yezid, günlerce defnedilmesine izin vermemiş Habbâbe'nin cesedini öpüp, koklamıştı. Ceset kokmaya başlayınca Mesleme onun, Müslümanların Halifesi olduğunu hatırlatarak uyarmış ve insanların içerisine bitkin haliyle çıkmasını engellemişti. Habbâbe'nin ardından kendini toparlayamamış, pek çok rivayete göre, Habbâbe'nin ölümünden yaklaşık onbeş gün sonra 26 Şaban 105/28 Ocak 724 Cuma günü ölmüştür. ${ }^{24}$

23 Belâzurî, Ebû'l-Hasan Ahmed b. Yahya b. Cabir, Fütuhü'l-Buldan, (thk. Rıdvan Muhammed Ridvan, Matbatü'l-Misriyye, Kahire 1932), 415; Yakubî, II, 241; İbni Abdirabbih, IV, 442; Ezdî, 17; Mes'udî, Muruc, III, 217; İsfehanî, VII, 7-8; İbnü'l-Cevzî, IV, 536; İbnü'l-Esîr, IV, 347; Ebû'l-Fida, İsmail İmamüddin, Tarihu Ebû'l-Fida, (I-IV, Tab'atü'l-Hüsniye, Misır tsz.), IV, 203; Nüveyrî, XXI, 393; İbni Kesîr, IX,233; İbni Haldun, Abdurrahman b. Muhammed, Kitabü'l-íber ve Divanü'l-Mübtedei ve'-Haber fi Eyyami'l-Arab ve'l-Acem ve'l-Berber ve Men Aserehüm Min Zevi's-Süldani'l-Ekber (Tarihi İbni Haldun), (thk. Halli Şehade, Süheyl Zekkar, I-VIII, 3. Bask., Darü'l-Fikr, Beyrut 1996),III, 80.

24 Hayyat, 259; Belâzurî, Ensâb, VIII, 243, 261, 267; Dineverî, 320; Yakubî, II, 242; Taberî, VII, 21 25; İbni Abdirabbih, IV, 444-445; Ezdi, 18,20,21; Mes'udî., Muruc, III, 195-205; Kitab at-Tanbih ve'-İşraf, (thk. M.J.De Goeje Matbaat-1 Brill, Leiden 1968), 320; İsfehanî, XV,140-141; İbn Hamdun, IX, 226; İbnü'l-Cevzî, IV, 576-578; İbnü'l-Esîr, IV, 367; Yakut b. Abdullah el-Hamevî er-Rumî, Şihabüddin Ebî Abdullah, Mu'cemül-Büldân, (thk. Ferid Abdülaziz el-Cündi, I-VII, Darü'l-Kutübü'l-İlmiye, Beyrut tsz.), I, 200 ; Ebû'l-Fida, IV, 203; Nüveyrî, XXI, 400; İbni Kesîr, IX, 231, 243; Zehebî, Tarih, VI, 281; A'lam, V, 152; Kitabu Düvelül-İslam, (thk. Fehim Muhammed Şeltevet, 
Ölüm sebebininen basit ifadeyle "kara sevdadan" olduğu belirtilse de ${ }^{25}$ gerçek sebebin akciğer hastalığı olan verem/tüberküloz olduğu anlaşılmaktadir. $^{26}$

\section{YEZID B. ABDÜLMELIK DÖNEMI IÇ POLITIKASI}

\section{A. GENEL GÖRÜNÜM}

Yezid devlet başkanı olduktan sonra bir süre, kendinden önceki devlet başkanı Ömer b. Abdülaziz'in takip ettiği barışçı siyaseti izlemeye çalışmıştır. ${ }^{27}$ Ancak bunun uzun sürmediği ve valilere yazdığı bir yazı ile Ömer öncesi uygulanan politikalara dönülmesini istediği anlaşılmaktadır. ${ }^{28}$

Ömer b. Abdülaziz'in ülke içerisinde uygulamaya soktuğu barışçı politikayı Yezid'in tamamen değiştirmesi, sükunetin bozulmasında başlıca etken olmuştur. İslâm dünyasındaki Arapların geleneksel Kays'lı ve Yemenli olarak kutuplaşmaları, Ömer döneminde uygulanan politikalarla küllenmeye başlamıştı. Ancak Yezid döneminde Yezid'in kendisinin bizzat taraf olması nedeniyle bu eski rekabet yeniden canlanmış ve Emevîlerin yıkılışında önemli rol oynamıştır. ${ }^{29}$

Haccac'ın yeğeni olan, eşi Ümmü'l-Haccac'ın etkisiyle Yezid'in Mühelleb oğulları gibi Emevîlere hizmeti geçmiş sadık, asil ve kudretli bir aileyi düşman sayması, Yemenlilere savaş ilanı demekti. Yezid bu hareketiyle devlet adamlığından çok kin ve kabilecilik duygularıyla düşünmeden, ölçmeden danışmadan karar veren bir profil çizmektedir.

Yezid b. Mühelleb isyanından sonra aşırı Kays taraflısı olan Ömer b. Hubeyre'yi tam serbesti ile Yezid b. Mühelleb'in yerine Irak'a vali yapması ve İbni Hubeyre'nin oradaki yanlı uygulamaları sonucu Kayslı-Yemenli çekişmesini

Muhammed Mustafa İbrahim, Heyetü'l Mısrıyye Amme Li'l-Kitab, I-II, Misır 1974), I, 74; İbnü'lVerdî; Zeynüddin Ömer, Tarihu İbnü'l-Verdî, (Cemiyyetü'l-Meârif, ?- tsz.), 183; İbni Haldun, III, 85; Suyutî,283; Kalkaşandî, III, 267; İbn Habib, Muhabber, 29; İbn Kuteybe, Meârif, 250; Müberred, Ebî'l-Abbas, Muhammed b. Yezid, el-Kamil fi'l-Lugat

25 İbni Tiktaka, Muhammed b. Ali b. Tabataba, el-Fahri fi'l-Adabi's-Sultaniye ve'd-Düveli'l-İslamiye, (Darü'l-Kütübi'l-Arabiyye, Kahire h.1317), 117.

26 İbnü'l-Esîr, IV, 367; Zehebî, Tarih, VI, 281; A'lam, V, 152; İbni Kesîr, IX, 232. İbni Abdirabbih ölüm sebebi olarak "veba" hastalığını göstermektedir. (Bkz. İbni Abdirabbih, IV, 445.).

27 Belâzurî, Ensâb, VIII, 262; İsfehanî, XXIII, 157; İbnü'l-İmad, Şezerât, II, 28; Yafiî, Ebû Muhammed Abdullah b. Esad b. Ali b. Süleyman, Mir'atü'l-Cinan ve İbretü'l-Yekzan, (Darü'l-Kitabü'lİslamî, I-IV, Kahire 1993), I, 224; Suyutî, 282; Zehebî, A'lam, V, 151; Tarih, VI, 280; Yıldız, "Yezid b. Abdülmelik" İ.A. Mad., XIII, 411.

28 İbni Abdirabbih, IV, 441; Hammade, M. Mahir, Dirasetu Vesikıyye Li Tarihi'l-İslam Ve Masadiruhu, (Müessesetü'r-Risale, Beyrut 1988), 66.

29 Hitti, Philip K., Siyasi ve Kültürel İslam Tarihi, (Çev. Salih Tŭ̆, Boğaziçi Yay. I-IV, İstanbul 1980), IV, 432; Wellhausen, Julius, Arap Devleti ve Sukutu, (Çev. Fikret Iş1ltan, A.Ü.İ.F. Yay. Ankara 1963), 152; Üçok, Bahriye, İslam Tarihi Emevîler-Abbasîler, (2. Bask., M.E.Basımevi, Ankara 1983), 70. 
artırması, Yezid'in politikalarındaki bilinçsizliği teyit etmektedir. ${ }^{30}$ Yezid b. Ebî Müslim, Berberîlerce, tasvip edilmeyen uygulamaları nedeniyle öldürülmüş ve yerine eski vali getirilmişti. Bu durum Yezid'e bildirilmiş, Yezid b. Abdülmelik ise bu fiili durumu bir süre de olsa, kabul etmek zorunda kalmıştı. ${ }^{31} \mathrm{Bu}$ olay da gösteriyor ki Yezid b. Abdülmelik, etraflı, derin, geniş ve uzun vadeli düşünememektedir. Günlük politikalarla devlet idaresine yön vermektedir.

Yezid b. Ebî Müslim'in öldürülmesi ve yeni Kuzey Afrika Valisinin atanmasıyla ilgili detaylarda Yezid b. Abdülmelik, Berberîlerce öldürülen valinin yerine geçirilen, Muhammed b. Evs el-Ensari'nin nasıl birisi olduğunu sormuş, dindar, alim birisi olduğunun söylenmesine rağmen "Kureyşli mi?" diye soruyu tekrarlamıştır. "Hayır" cevabını aldıktan sonra "hiç Kureyş'li" yok muydu?" demiştir. "Var ama görevi kabul etmedi" cevabından sonra Kelb kabilesinden olan Bişr b. Safvan el-Kelbî’yi Kuzey Afrika Valiliğine atadığını görüyoruz. ${ }^{32}$ Burada iki nokta dikkat çekmektedir. İlk nokta, Kuzey Afrika'ya Vali atamasında görüldüğü gibi Yezid için dindarlık ve ilim gibi meziyetlerin (en azından) ilk planda önemli olmadı̆̆ıdır. İkinci nokta ise, Kureyşlilik gibi geniş bir çerçevede dahi olsa, akrabalarına atamalarda öncelik verdiğidir.

Yezid, Ömer b. Abdülaziz'in hapsettiği Ehvas ve "iblis" diye nitelediği Yezid b. Ebî Müslim gibi şahsiyetlere de değer vermiştir. Ehvas'ı sürgünden getirtip, sarayda itibar verirken, Ömer b. Abdülaziz'in ordusunda bile bulunmasını istemediği Yezid b. Ebî Müslim'i, Afrika Valiliği gibi çok önemli bir makama getirmiştir. ${ }^{33}$ Görüyoruz ki Yezid, Ömer döneminde saygınlığı olmayan ya da saraydan kovulmuş insanlara itibar edip, ikramda bulunmuştur. ${ }^{34}$

Yezid'in hilafete geçişinden bir süre sonra, gösterdiği performanstan alimlerin memnun olmadıkları hatta çekindikleri, dönemin meşhur alimlerinden İbni Sirîn, Şa'bî ve Hasan-1 Basrî ile Yezid'in Irak Valisi arasında geçen konuşmalardan ortaya çıkan bir gerçektir. ${ }^{35}$ Yezid'in biraz da eğlenceye çok zaman ayırmasından kaynaklanan gidişatındaki memnuniyetsizliğin, Kureyş'in ileri gelenlerini ve Ümeyyeoğullarının seçkinlerini harekete geçirdiği anlaşılmaktadır. İbn Kuteybe'nin bildirdiğine göre Yezid kendisini görevden almak iste-

30 Wellhausen, 152-153.

31 Cahşiyarî, Ebû Abdullah Muhammed b. Abdusu, Kitabü'l-Vüzarai ve'l-Küttab, (thk. Mustafa Saka, 2. Bask., Matbaat-1 Halebi, Kahire 1980), 57; Taberî, VI, 617; İbnü'l-Esîr, IV, 353; İbni Tağriberdi, Ebû'l-Mehasin, en-Nucumu'z-Zahire fi Müluki Misr ve'l-Kahire, (I-XII, Kahire 1929-1956),I, 245.

32 İbnü’l Kasım, Ebû İshak İbrahim, Tarihu Iffrikıyye Ve’l-Mağrib, (thk. Abdullah Ali Zeydan, İzzeddin Ömer Musa, Darü'l-Ğarbi'l-İslami, Beyrut 1990).

33 İsfehanî, IV, 246, 248, IX,79-81; İbni Hallikan, Ebû'l-Abbas Şemsüddin Ahmed b. Muhammed b. Ebî Bekr, Vefeyatü'l-A'yan ve Enbaü Ebnai'z-Zeman, (thk. İhsan Abbas Darü' Sadr, I-VIII, Beyrut tsz.), VI, 310; Vaglari,Laura, İslam Tarihi Kültür ve Medeniyeti, II,403; İbnü’l-İmad, Şezerât,II, 28. 34 Wellhausen, 153.

35 Belâzurî, Ensâb, VIII, 275; Mes'udî, Muruc, III, 202; İbni Hallikan, II, 71; İbni Hamdun, I, 162 163. 
yen bu birlikteliğe karşı, sert tavır almış, hapis ve hatta ölüme varan cezalar vermiștir. ${ }^{36}$

Yezid'in yönetimde kötü gidișatından rahatsız olanlardan biri dekardeşi Hişam idi. Bu yüzden aralarında bir düşmanlık meydana geldiği bilinmektedir. ${ }^{37}$

Habbâbe'nin Yezid üzerinde önemli ölçüde nüfuzu vardır ve bunu Irak Valiliğine Ömer b. Hubeyre'nin atanmasında açıç̧a görüyoruz. Sarayda ve valiler üzerinde etkisi olabileceğini yukarıda verdiğimiz bu haberlerden çıkarabiliyoruz. Ancak bu örneklerden hareketle ve eğlence sırasında Yezid'in söylediği bir sözden dolayı "onun devletin bütün işlerini, Habbâbe'nin eline bıraktığ 1 , Habbabe'nin ise istediğini atadığ 1 , istediğini azlettiği" gibi bir sonuca ulaşmak bizce abartılıdır. Hele bu tek bir örnekten yola çıkarak, "Halifeden bir şey elde etmek isteyenler Habbâbe'ye ve Sallâme'ye başvuruyorlardı" 39 diyebilmek bizce mümkün görülmemektedir.

Yezid'in özellikle iki şarkıcıyla eğlenceye çok zaman ayırdığını ve devlet işlerini bu yüzden ihmal ettiği görüşünü daha önce belirtmiştik. Ancak gerek Horasan, Hazar, Ermeniye bölgeleri ve gerekse diğer bölgelerde yapılan fetihler becerikli komutanlar eliyle, fakat Yezid'in bilgisi dahilinde olduğunu unutmamak gerekir. Yezid'in devlet işleriyle tümüyle ilgilenmediği hususu bu yüzden doğru değildir. Sübeyt en-Nehranî̀yi Hazarlarla yaptığı savaşı kaybetmesi üzerine sorguya alıp nedenini araştırması ve dahası işin peşini bırakmayıp aynı bölgeye tecrübeli komutan Cerrah b. Abdullah'ı göndermesi bu ilginin açık bir göstergesidir. ${ }^{40}$

\section{B. HIRISTIYANLARLA ILIŞKILER}

Yezid'den önceki halife Ömer b. Abdülaziz devlet içerisinde estirdiği barışçıl politikaları çerçevesinde Hıristiyanlara da adaletli davranmıştı. ${ }^{41}$ Hıristiyanlara karşı kaba bir tavır takınan Yezid b. Abdülmelik ise, onları özel bir elbise giymeye mecbur tutmuş ve ibadetlerini açıktan yapmalarını yasaklamıştı. ${ }^{42}$

36 İbn Kuteybe, İmame, II, 103-104.

37 İbni Kuteybe, Kitabu Uyunu'l-Ahbar, (thk. Muhammed İskenderani, Darü'l-Arabi, I-IV, 3. Bask., Beyrut 1997), III, 117; İbni Abdirabbih, IV, 443-444; Mes’udî, Muruc, III, 202; İbni Kesîr, IX, 231232; Hasan, Hasan İbrahim, Siyasi Dini Kültürel İslam Tarihi , (Çev. İ.Yiğit, S.Gümüş, I-XI..., 3.Bask., Kayıhan Yay. İstanbul 1991), I, 420.

38 Üçok, İslam Tarihi, 72.

39 Wellhausen, 153; Yıldız, "Yezid b. Abdülmelik" İ.A. Mad., XIII, 411.

40 İbnü'l-Esîr, IV, 360; Dahlan, Zeynî, Ahmed b. Zeyni, Fütuhat-ı İslamiye Ba'de Meda'l-FutuhatinNebeviyye, (Matbaat-1 Mustafa Muhammed, I-II, Kahire H. 1354), I, 241.

41 Vaglari, İslam Tarihi Kültür ve Medeniyeti, I, 105.

42 Miquel, Andre, İslam ve Medeniyeti, Doğuştan Günümüze, (Çev. Ahmet Fidan, Hasan Menteş, Birleşik Dağıtım Kitabevi, I-II, Ankara 1991), I, 118. 
Yezid b. Abdülmelik'in Hıristiyanlara karşı bu olumsuz yaklaşımını daha ileri götürdügünü ve bir emirle, duvarlar, taşlar, tahtalar ve kitaplar üzerindeki canlı resimlerin kaldırılmasını istediği ve bu canlı resimlere ibadet edilmesini yasakladığ ${ }_{1}$ anlaşılmaktadır. ${ }^{43}$

Elde ettiğimiz sınırlı bilgilerden, Antakya'da bir kilisenin yapımına izin vermesine rağmen, ${ }^{44}$ Yezid'in Hıristiyanlara iyi davranmadığı, İslam'ın gerektirdiği hoşgörüyü göstermediği ortaya çıkmaktadır. Hatta İslam'ın yasakladığ lamaya çalışarak bu hoşgörünün aksine davrandığı görülmektedir.

\section{EKONOMI POLITIKASI}

Yezid b. Abdülmelik'in etkin bir ekonomi politikası olduğu yönünde bir bilgi ve izlenim bulunmamaktadır. Ancak sınırlı bilgilerden bazı sonuçlar çıkarabiliyoruz.

Yezid, kendinden önceki devlet başkanı Ömer b. Abdülaziz'in uygulamasına son vererek Müslüman olmayan Araplardan tekrar vergi almaya başlamış, çeşitli bölgelerden gelen vergileri az bularak yeni bir vergilendirme yoluna gitmişti. Hatta düşmanlığını yaptığı Yemenlilerin vergilerinin artırılmasını isterken "aç kalsalar bile onlardan alın" şeklindeki sözleri ne derece acımasız bir vergi politikası getirdiğinin bir göstergesi olmuştur. ${ }^{45}$

Bu vergi politikasının bir yansıması da Kuzey Afrikada tepki olarak ortaya çıkmıştı. Yezid b. Abdülmelik hilafete geçişinden sonra Afrika'ya vali atadığg Yezid b. Ebî Müslim'in yerli halk (Berberîler) tarafından öldürülüşünün nedenlerinden birisi de, Müslüman gayri Arap unsurlardan yeniden vergi almak istemesidir. Bu uygulama ile halk arasında huzursuzluklar çıkmış ve sonunda öldürülmüştür. ${ }^{46}$

43 İbni Tağriberdi, I, 250; Gregory Ebû'l-Ferec, Ebû'l-Ferec Tarihi, (Çev. Ömer Rıza Doğrul, T.T.K. Yay., I- II, Ankara 1995),. I, 194; Brockelmann,C., İslam Uluslart ve Devletleri Tarihi, (Çev. Neşet Çağatay, T.T.K. Yay., Ankara,1992),74. Brockelmann bu bilgiyi verdikten sonra bir açıklama ile Wellhausen'in bu bilgiyi kabul etmediğini, ancak Müslüman ve Hıristiyan kaynakların bunu doğruladıklarını belirtmiş̧ir. Bazı kaynaklarda bu haber 102/721'de Yezid putların kırılmasını emrettiği şeklinde geçmektedir. Bkz. el-Bekrî, Ebû Ubeyd Abdullah b. Abdulaziz b. Muhammed, Kitabu'l-Mesalik ve'l-Memalik, (thk. P. Van Leeuwen, A. Ferre, Darü'l-Garb el-İslami, I-II, Tunus 1992), II, 604-605; İbni Abdi'l-Hakem, Abdurrahman b. Abdullah, Futuhu Misr ve Ahbaruha, (Yale Üniversity Press, New Haven, Leidein 1920), 114.

44 Arnold,T.W., İntişar-ı İslam Tarihi, (Çev. Hasan Gündüzler, 2. Bask., Akçă̆ Yay., Ankara 1982), 80.

45 İbnü'l-Esîr, IV, 331; İbni Tağriberdi, I, 239.

46 Taberî, VI, 617; İbnü’l-Esîr, IV, 353; Nüveyrî, XXI, 393; İbni Tağriberdi, I, 245; Aycan, İrfan, "Emevîler Dönemi İç Siyasi Gelişmeleri”, (A.Ü.İ.F. Dergisi, Sayı XXXIX, AÜiF Yay., Ankara 1999), 169. İbnü'l-İzari ve Belâzurî öldürülme sebebi olarak ellerine yazı damgalamak istemesini göstermektedirler. Belâzurî, Fütuh, 232; İbnü'l-İzari el-Merakuşi, ,el-Beyanü'l-Muğrib fi Ahbari'l-Endelusî ve'l-Mağrib, (thk. S. Kolan, nşr. L. Provençal, I-II, E.J.Brill, Leiden 1951),I, 48-49. 
Emevîlerin en değerli üç parasından biri kabul edilen "Hubeyriye" denilen paraların, Yezid döneminde, 103/722 yılında Irak Valisi Ömer b. Hubeyre tarafından bastırılması da ${ }^{47}$ bu dönem için dikkate değer bir başka noktadır.

\section{ISYANLAR}

Yezid b. Mühelleb isyanı, Yezid dönemindeki devleti zayıflatan, meşgul eden en büyük isyandır. Nedeni, V. Emevî devleti başkanı Abdülmelik dönemindeki Haccac taraftarlarının iktidar mücadelesi sırasında katledilmesine kadar giden Kaysl1-Kelbli mücadelesine kadar uzanır. Mühellebîler ailesi gibi şeref ve kahramanlıkları ile bilinen, Emevîlere yıllarca sadakatle hizmet etmiş bir ailenin siyasi tarihten silinmesiyle sonuçlanan ${ }^{48}$ bu isyandan başka, devletin bastırmada güç harcadığı, uğraşmak zorunda kaldığı birkaç Haricî isyanı daha çıkmıştı. Ancak Yezid b. Mühelleb isyanı gibi, bu isyanlar da tek tek bastırılmiştr. ${ }^{49}$

Yezid b. Abdülmelik dönemi, gerek Abbasî hareketinin ortaya çııışı ve çalışmalarına başlamas $1^{50}$ ve gerekse Haricîlerin çeşitli isyanlarda boy göstererekdevleti zayıf düşürmeleriyle de önemli bir dönemdir. Özellikle, Ömer b. Abdülaziz döneminde Halifenin tutumu nedeniyle daha sakin olan Haricîlerin sonradan, idaresinden memnun olmadıkları Yezid döneminde bir çok isyanla ortaya çıkmaları dikkat çekicidir. Yezid'in şahsi politikaları Haricilerin, Emevî devletini zayıf düşüren isyan ve itaatsizliklerine neden olmuştur. ${ }^{51}$

\section{YEZID B. ABDÜLMELIK DÖNEMI VE DIŞ POLITIKASI}

Yezid b. Abdülmelik dönemi önemli ve dikkate değer fetihlere sahne olmamıştır. Gerek karmaşık çekişmelerle dolu iç siyaset ve gerekseyönetimin zayıflı̆̆ı dışarıya fetihlerin zayıf kalması şeklinde yansımıştır. Emevî Devleti sınırları nisbeten daha sakin bir dönem geçirmiştir. Birkaç ayaklanmanın bastırılması, olağan dışı birkaç olaya müdahale veya devletin gücünü gösterdiği birkaç fetih ve savaş dışında askeri hareketliğin daha az olduğu görülmektedir. Yezid b. Abdülmelik'in dört yıllık bu kısa döneminde en canlı sınır cepheleri, Bizans, Ermeniye ve Hazar Cepheleri olarak görülmektedir. ${ }^{52}$

47 Belâzurî, Fütuh, 454; İbni Haldun, I, 323; III, 57; İbni Kesîr, IX, 230; Makrizi, Takıyuddin Ahmed b. Abdulkadir, Kitabu's-Suluk li Ma'rifeti Düveli'-Müluk, (thk., M. Mustafa Zeyade, I-XII, 2. Bask., The National Library Press, Kahire 1973), 378; Vaglari, İslam Tarihi Kültür ve Medeniyeti, II, 572. 48 Hasan, H.ì., II, 291.

49 Taberî, VI, 576-578; Ezdi, 6-7; İbnü'l-Cevzî, IV, 536; İbnü'l-Esîr, IV, 332-333; Nüveyrî, XXI, 375; İbni Kesîr, IX, 219; Demircan, Adnan, Haricîlerin Siyasi Faaliyetleri, (Beyan Yay. İstanbul 1996), 145. 50 Dineverî, 319; Yakubî, II, 239; Taberî, VI, 616; İbnü'l-Esîr, IV, 323; İbni Haldun, III, 125.

51 Şakir, Mahmud, Hz. Ademden Bugüne İslam Tarihi, (Çev. Ferit Aydın, I-IV, Kahraman Yayınları, İstanbul 1993), III, 343.

52 Takkuş, Muhammed Süheyl, Tarihu Devletü'l-Emevîyye, (Darü’n-Nefais, Lübnan 1966)150. 


\section{FETIHLER VE ASKERI HAREKÂTLAR}

\section{A. TÜRKLERLE MÜCADELELER}

Doğu komşusu Çin'e karşı her hangi bir girişimde bulunamayan Türkeş Hakanı Sulu, kendi menfaatleri açısından daha uygun bulduğu batıya yönelmiştir. Maveraünnehir'de yerel beylerin desteğini alarak 102/721 yılında Semerkand'a Kursul komutasında askeri birlikler göndermiştir. ${ }^{53}$

Yezid'in Horasan Valisi, yumuşak huyu ve müsamahakâr tavrıyla eleştirilen Huzeyne (Hanım) lâkaplı Said b. Abdülaziz, ${ }^{54}$ Kursul komutasında ki Türklere karşı bazı askeri başarılar kazanmışsa da sonuçta yenilmiştir. Semerkand'da bulunan Arap garnizonu ise, Türkeş Hakanının burayı muhasara edecek kadar güçlü olmaması nedeniyle herhangi bir saldırıya uğramamıştır. ${ }^{55}$

\section{B. SOĞDLULARLA MÜCADELELER}

102/721 y1lında verdikleri sözden dönen ve Müslümanların karşısındaki Türklere yardım eden Soğdlular ${ }^{56}$ ile Said Huzeyne savaştı. Said, karşısına çıkan bir grubu yenip ilerledi. Müslümanlar "More" yakınlarındaki bir vadiye geldiklerinde Türklerin pususuna düştüler. Önce yenildiyseler de, sonradan toparlanıp üstünlük sağladılar. ${ }^{57}$

Said, Soğdlularla savaşmak istemediğinden onlara görüşme çağrısında bulunmuş, kabul edilmeyince üzerlerine yürümüştür. ${ }^{58}$ Said'in bütün Soğd kalelerini fethettiğini ve hedefine ulaştı̆̆ını Belâzurî kaydetmektedir. ${ }^{59}$

53 Yıldız, D. Hakkı, İslamiyet ve Türkler, (İ.Ü.E.F. Yay., İstanbul 1976), 20; Hudari,D.GüN.B. İ.T. , II, 416; Hamilton, H.A.R. Gibb, Orta Asyada Arap Fütühatı, (Çev. M. Hakkı, Evkaf Matbası, İstanbul 1930), 51.

54 Taberî, VI, 607; İbnü’'-Esîr, IV, 347; İbni Haldun, III, 80; Belâzurî, bu lakabı aynı sebeple "Huzayfe" yani dihkan (toprak ağası) hanımı olarak vermektedir. Bkz. Belâzurî, Futuh, 416.

55 Yıldız, İslâmiyet ve Türkler, 20-21; "Yezid b. Abdülmelik" İ.A. Mad., XIII, 410. Taberî ve diğer Müslüman tarihçiler Kasr-ı Bahili savaşı olarak değindikleri bu olayı genişçe aktardıktan sonra Türklerin yenildiğini, ancak Müslümanların ele geçirdikleri Bahili Sarayını, o gece terkettiklerini, ertesi gün geri dönen Türklerin sarayı boş görünce şaşırdıklarını haber vermektedirler. (Bkz. Taberî, VI, 607 vd., İbnü'l-Esîr, IV, 347-350; İ̉ni Kesîr, IX, 222-223; Nüveyrî, XXI, 375-376; İbni Haldun, III, 80-81; Dahlan, II, 236-238.)

56 Orta Asya'da bir yer ismi olan Soğd, İstahri'ye göre Buhara'nın doğusundan Dabusiya'dan Semerkant'a kadar olan yerleri kapsamaktadır. Aynı kaynak buraya Buhara, Kişş (Kaş) ve Nesef in de dahil edildiğini aktarmaktadır. Bölgenin merkezi olarak bazen Kişs, bazen Semerkand gösterilmektedir. Soğdluların kendilerine özel dilleri ve gelenekleri vardı. Bu konuda detay için bkz. Barthold, “Soğd” İ.A. Mad., X, 736. (Ayrıca, bkz. Yakut, Mu'cemu'l-Buldan, III, 464-466). Ancak Zeki V. Togan, son dönem tarihçilerin İran kökenli kabul etmelerine rağmen, aralarında Soğd beyinin de bulunduğu beylerin Türk aristokrasisine mensup olduklarını belirtmektedir. (Bkz. Togan, Zeki V. Umumi Türk Tarihine Giriş, (2. Bask., İ.Ü.E.F. Yay., İstanbul 1970) 75).

57 Taberî, VI, 612-614; İbnü’l-Esîr, IV, 350; İbni Haldun, III, 81-82; Nüveyrî, XXI, 377.

58 Hayyat, 256; Belâzurî, Futuh, 416.

59 Belâzurî, Futuh, 416. 
Said Huzeyne'den sonra Horasan valisi olan Said b. Amr el-Hareşî Türklere yardım eden Soğdlulara çok şiddetli davranınca, halk oturdukları yerleri terk etmeye mecbur oldu. Said teslim olanları bile kılıçtan geçirmiştir. ${ }^{60}$ Valinin 103 sonu ve 104 yılı başlarında (722)meydana gelen bu olaylardaki sert tavırları, Emevîlere karşı kin ve nefretin artmasına neden olmuştur. ${ }^{61}$

Horasan Valisi Müslim b. Said el-Kilâbi ise,105/724'de bazı küçük başarılar kazanarak Afşina'ya kadar ilerledi. Ancak esas hedefi olan Fergana'ya ulaşamadi. ${ }^{62}$

\section{HAZARLARLA MÜCADELELER}

Cerrah b. Abdullah'ın ön plana çıktığı Hazar Cephesi Yezid b. Abdülmelik döneminin en çetin mücadelelerinin geçtiği cephedir. ${ }^{63}$

Hazarlar 103/722 yılında Lân'a küçük çaplı bir yağmalama akınında bulunmuşlardı. ${ }^{64}$ Büyük ihtimalle Yezid b. Abdülmelik bu akına karşılık Sübeyt en-Nehranî komutasında bir orduyu ertesi sene Hazarlar üzerine göndermişti. ${ }^{65}$ Kıpçak ve diğer Türk boylarından bazılarının da desteğini alan Hazarlar, Sübeyt'i ağır bir yenilgiye uğratmışlardı. Bu yenilgi üzerine Yezid, komutan Sübeyt'i azarlayarak, yenilginin sebebini soruşturmuştur. ${ }^{66}$

Yezid öyle anlaşılıyor ki bu konuya çok önem vermiş ve Sübeyt'in yenilgisinin intikamını almak üzere deneyimli komutan Cerrah b. Abdullah elHakemî̀yi Ermeniye Valiliğine atayarak Hazarlarla mücadelede bizzat görevlendirmiştir. ${ }^{67}$ Cerrah, Hazarları gafil avlayarak yenmeyi başardı ve Derbend'i ele geçirdi. Hazarlar üzerine gitmeye devam eden Cerrah, Husayn kalesinden sonra, Hazarların en önemli şehirlerinden olan Belencer'e kadar bir çok kale ve şehri fethetti. Cerrah, 104/722 yılında önemli bir savaş olan Belencer kuşatmasından da her iki tarafın ağır kayıpları olmasına karşın zaferle döndü. ${ }^{68}$ Kışın yaklaşması ve Hazarların karşı hücum hazırlıkları üze-

60 Yakubî, II, 238; Taberî, VII, 7-8; İbnü'l-Esîr, IV, 358-359; İbni Haldun, III, 82-83; İbni Kesîr, IX, 229; Dahlan, II, 239-240; Hamilton, Orta Asya, 52-53; Wellhausen, 214.

61 Yıldız, İslâmiyet ve Türkler, 21.

62 Yıldız, İslâmiyet ve Türkler, 21; "Yezid b. Abdülmelik" İ.A. Mad., XXIII, 410; Wellhausen, 216; Hudari, D.GÜN.B. I.T., II, 416. Afşina, Horasandaki Semerkant'ta bir yerleşim yeri. (Bkz. Yakut, Mu'cemu'l-Buldan, I, 274). Fergana Maveraünnehir'de Türkistan'da geniş bir bölge. (Bkz., Yakut, Mu'cemu'l-Buldan, IV, 287-288).

63 Hudari, D.GÜN.B. İ.T., II, 416.

64 Yakubî, II, 243; Taberî, VI, 619; İbnü'l-Esîr, IV, 356.

65 Yıldız, İslâmiyet ve Türkler, 26.

66 İbni A’sem, IV, 260; İbnü’l-Esîr, IV, 360; Nüveyrî, XXI, 381.

67 İbnü'l-Esîr, IV, 361.

68 Yakubî, II, 240-241; Taberî, VII, 14-15; İbni A’sem, IV, 262-263; İbnü’l-Esîr, IV, 361-362; Nüveyrî, XXI, 382; İbni Kesîr, IX, 230; İbni Haldun, III, 83; Dahlan, I, 242. Zehebî bu olayı Nehr-ü-Ran vakası olarak niteliyor ve şöyle diyor, “104 yılında Cerrah’ın komutasındaki Müslümanlarla, İbn 
rine, Cerrah, Belencer'i terk ederek Derbend'e döndü ve Halife Yezid'den destek istedi. ${ }^{69}$

\section{BIZANS VE ANADOLU SEFERLERI}

Emevîler döneminde, İslâm'ın değerlerini daha ileriye götürmek ve Bizans'1 doğudan sıkıştırmak amacıyla mevsimlik akınlar şeklinde yapılan fetihler, Toros dağlarından Kapadokya'ya uzanan hat boyunda sınırlı kalmıştı. ${ }^{70}$

Bizans'a karşı geniş çaplı askeri harekat yapılmamakla beraber, her yaz yapıla gelen ve Ömer b. Abdülaziz döneminde kesintiye uğrayan Anadolu seferleri, Yezid b. Mühelleb isyanının bastırılmasının ardından yeniden başladı. Ancak bundan sonra yapılan seferler önemli bir sonuç alınamayan, yağma yapılıp terk edilen kale fetihleri olarak göze çarpmaktadır. ${ }^{71}$

\section{E. ENDÜLÜS VE AFRIKA}

Yezid döneminde önemli bir başarı göremediğimiz Endülüs'te ise, Vali Semh, Ömer b. Abdüllaziz döneminde ki Preneler ötesindeki fethine devam etmek amacındaydı. Dük Eude ile hakimiyetindeki Akitanya'nın başkenti Toulouse (Tuluz) önlerinde karşılaştı. Müslümanlar yapılan şiddetli savaşta yenildi. $(102 / 721)^{72}$

Yezid'in kısa döneminde, Müslümanlar bazı kısmi başarılarla Endülüs’te içerlere ilerlemeye devam etmişledir. 103/722 yılında Kuzey Afrika Valisi Bişr b. Safvan tarafından Endülüs Valiliğine getirilen Anbese b. Süheym el-Kelbî̀3 Gaule(Galya-Frank) topraklarına yeniden akınlara başladı. Septimanya bölgesini fethederek Ren (Rhone) nehrine kadar ulaşt1. ${ }^{74}$ Anbese, daha sonra Liyon şehrini ele geçirmiş Bergonya bölgesinin içlerine kadar ilerlemiştir. ${ }^{75}$

Sözünü ettiğimiz iç karışıklıklara Valiler de dahil, yönetimin zaafları eklenince, Yezid b. Abdülmelik döneminde dışarıda da etkin bir varlık gösteri-

Hakan komutasındaki kafirler Babü'l-Ebvab yakınlarında karşılaştı. Müslümanlar galip gelerek esirler ve ganimetler aldılar". (Bkz. Zehebî, Tarih, II, 12).

69 İbni A’sem, IV, 263; İbnü'l-Esîr, IV, 362; Nüveyrî, XXI, 383; İbni Haldun, III, 84.

70 Takkuş, 150.

71 Uçar, Şahin, Anadolu'da İslâm-Bizans Mücadelesi, (İşaret Yayınları, İstanbul 1990), 119; Hudari, D.GÜN.B.I.T., II, 417; Yıldız, "Yezid b. Abdülmelik" I.A. Mad., XXIII, 411.

72 Provençal, E. Levi, Histoire de Espagne Musulmane, (E.J. Brill, I-II, Leiden, 1950), 58; Na'na'i, Abdülmecid, Tarihu Devleti'l-Emevîyye fi'l-Endülüs, (Darün-Nehda, Beyrut, 1987), 99; Hudari, D.GüN.B. İ.T., II, 417, IV, 69; Vaglari, İslam Tarihi Kültür ve Medeniyeti, I, 107; Hitti, III, 786; Hasan,H.İ., I, 405; Algül, Hüseyin, İslam Tarihi, (Gonca Yay., I-IV, İstanbul 1986), III, 48; Ülkü, Hayati, İslâm Tarihi, (Çile Yay., 6. Baskı, İstanbul, 1982),432.

73 İbn'ül-İzarî, II, 27; İbn'ül-Kutiyye, Muhammed b. Ömer el-Kurtubî, Tarihu İftitahi'l-Endülüs, (thk. Abdullah Enis, Müessesetü'l-Meârif, Beyrut 1994), 80.

74 Na'na'i, 100; Hasan,H.ì., I, 405.

75 Na'na'i, 100; Şakir, III, 349. 
lememiştir. Kısacası, Cerrah gibi önemli bir komutan sayesinde Maveraünnehir'de Türkler ve Hazarlara karşı nispeten iyi sonuçlar alınıp, bu bölgede birkaç yerleşim yerinin fethedilmesi, Anadolu'da Bizans'a karşı rutin hale gelen yaz akınlarında birkaç küçük kale fethi gerçekleştirilmesi dışında önemli sayılabilecek başarılar göremiyoruz.

\section{KÜLTÜR ve SANAT}

\section{A. MIMARî}

İncelediğimiz dört ylllık Halife Yezid $\mathrm{b}$. Abdülmelik döneminin mimarisinde alanında önemli bir değişiklik ve etkinlik olmadığını söylebiliriz. Yezid dönemi ileilgili, kaynaklarımızda sadece mimarîde değil, kültür ve sanat alananında da bir kaç istisna bilgi dışında yeterince bilgi ulaşmamıştır.

Yezid b. Abdülmelik'in Sasani örneğine göre kubbeli taraçalar üzerine ${ }^{76}$ yaptırdığı ve zaman zaman giderek, eğlenceli günler geçirdiğ $i^{77}$ Muvakkar sarayı, Şam'ın Belka nahiyesinde yer alıyordu..$^{78,79}$ Bu saray hakkında kapılar, ebatlar hatta kapıların üzerlerindeki süslemelere kadar detaylı bilgilere sahibiz. ${ }^{80}$

Araştırmacı antropolog Creswell, Ömer Camisi, Maşatta Sarayı ve Kasru't-Tûba'nın II. Yezid tarafından yaptırıldıkları yönündeki iddiaların yanlış olduğunu bilimsel olarak ortaya koymuştur. Örneğin Ömer Camiinde geçen 102 tarihi caminin yapım tarihi değil, camiye Yezid döneminde eklenen minarenin tarihi olduğunu ortaya koymaktadır. ${ }^{81}$

76 Brockelmann, 77; Barthold, Wassiliy V.- Köprülü, Fuad, İslam Medeniyeti Tarihi, (T.T.K. Basımevi, Ankara 1963), 135.

77 Creswell, A Short Account of Early Muslim Architecture, (Revised by James W. Allan, The American University in Cairo Press, England 1989), 113. İsfehanî, V, 213; Yakut, Mu'cemu'l-Buldan, V, 261. Yakut el-Hamevî er-Rumî, başka bir haberde Yezid b. Abdülmelik'in, Şam yakınlarındaki Belka'da Rakîm denilen yere gittiğini belirtmektedir. (Bkz. Yakut, Mu'cemu'l-Büldân, III, 69). Rahim denilen yerin Muvakkar Sarayı ile aynı bölgede olması, —isim farklılığı bir yana- bu iki yerin aynı yer ihtimalini düşündürmektedir.

78 Yakut, Mu'cemu'l-Büldân, V, 261. Suriye Çölünün güneybatı kesiminde Aynü'l-Temr denilen yere yakındı. Yakut el-Hamevî er-Rumî, bu bilgiyi verdikten sonra Yezid'in Muvakkar Sarayında bir azatlısının da bulunduğunu aktarmaktadır.

79 Muvakkar Sarayı ile ilgili olarak geniş bilgi için bkz. Erkoçoğlu, Fatih, “İmar Faaliyetleri”, Emevîler Dönemi Bilim, Kültür ve Sanat Hayatı, (Ed. Prof. Dr. İrfan Aycan), Ankara 2003, 178.

80 Creswell, K.A., Early Muslim Architecture, I-II, Oxford University Press, Oxford, 1932), I, 496497. Bu sarayın ortaya çıkarılan planı için bkz. Creswell, A. Short Accaunt, 132.

81 Creswell, Early, Muslim, Architecture, II, 490, 631; A. Short Account, 131. Basra Camii ve Yezid döneminde yaptırılan minaresinin ayrıntıları için bkz. Asfour, Abdulhalim, Emevî Devrinden Osmanlılara Kadar Suriye Minareleri, (A. Ü. Sos. B. Enst. İsl. Tar. Ve San. A.B.D., Basılmamış Y. Lisans Tezi, Ankara 1997), 27-28. 
Yezid dönemi Hıristiyan kiliseleri açısından farklı bir dönemdir. Çünkü II. Yezid döneminde bir taraftan Antakya'da kiliseler yaptırılmış ve açılış merasimleri düzenlenmiş, ${ }^{82}$ diğer bir taraftan ise Yezid kendisine gelen Yahudi bir kahinin Hıristiyan kiliselerindeki ikonaları (canlı resimleri) kaldırttığı takdirde kırk yıl hüküm süreceği kehaneti üzerine, Emevî Devleti sınırları içerisindeki bir çok kilisede bu yönde uygulamaya gitmiş ve ikonaların önemli bir bölümünü 102/721'de kazıttırmıştır. ${ }^{83}$

\section{B. MUSiKî ve EĞLENCE}

Yezid b. Abdülmelik döneminin en canlı alanlarından birisi de, musikî ve eğlence alanıdır. İsfehanî, Yezid'in musikîsi ve eğlence meclisleri, bu meclislerdeki konuşmalar, şairler, şiirler, özellikle Yezid ve iki kadın cariye şarkıcısı, Habbâbe ve Sallâme ile ilgili haberlere oldukça detaylı yer vermiştir. $^{84}$

Yezid'in Emevî Devlet başkanları içerisinde müziği çok seven ve şarkıcılarla çok fazla vakit geçiren bir kişiliği vardır, hatta şarkıcı cariyesi Habbâbe'nin ölümü ardından, onun kara sevdasına dayanamayarak öldüğü yolunda çok sayıda haber vardır. ${ }^{85}$ Halife Yezid, döneminin diğer eğlence araçları olan av partileri ve şarap içmede de kendisini göstermiştir. ${ }^{86}$

Def başta olmak üzere Emevîler döneminde kullanılan müzik aletleri Yezid b. Abdülmelik döneminde de kullanılmıştır. Ancak Ud'un Yezid için ayrı bir özelliği olduğu anlaşılıyor. Kendisine Ud'dan bahsedildiğinde nasıl bir şey olduğunu merak etmiştir. Öyle anlaşllıyor ki, Emevîler dönemi musikî hayatında Ud, Yezid b. Abdülmelik döneminde kendini göstermeye başlamıştır. Mes'udî'den gelen bir haberden, çok geçmeden Ud'un saray hayatına girdiğini görüyoruz. ${ }^{87}$

Ömer döneminde saraydan kovulan şairler ve şarkıcılar Yezid döneminde tekrar itibar bulmuşlardı. Ömer b. Abdülaziz'in şairlere yüz vermemesine karşın ${ }^{88}$ Yezid beğendiği şiirleri ödüllendiriyordu ve bu şairler arasında bir beklentiye yol açmışt1. ${ }^{89}$

82 Hatta bir açıllş töreninde, rakip mezhep taraftarlarının protestoları olmuştur. (Bkz. Arnold , 80). 83 Creswell, Early Muslim, Aarchitecture, I, 412-413; Wellhausen, 154.

84 Örnek olarak bkz. İsfehanî, I, 77, 252, II, 304, 338, IV, 245-248, XV, 127-130, 135, 138, XX, 340, XXI, 118.

85 Taberî, VII, 23; Aycan, İrfan, “íslam Toplumunda Eğlence Sektörünün Ortaya Çıkışı”, (A.Ü.i̇.F. Dergisi, Sayı XXXVIII, AÜIF Yay., Ankara 1999).180.

86 Hitti, II, 425.

87 Mes'udî, Muruc, IV, 18.

88 Zeydan, V, 277.

89 Bu konuya örnek olarak bkz. İbni Abdirabbih, VI, 37-38. 


\section{ILIMLER ve EĞiTiM}

Yezid döneminin bilimlerinin ve eğitiminin profilini çizecek önemli bilgilere sahip değiliz. Bu konuda birkaç küçük detay dışında bilgimiz yoktur. Yezid b. Abdülmelik döneminde, Ömer döneminin aksine alimlerin rahat olmadıklar1nı Yezid'den çekindiklerini görüyoruz. Şöyle ki, Irak Valisi İbni Hubeyre ile dönemin önde gelen üç alimi arasında geçen konuşmalarda, İbni Hubeyre, Yezid b. Abdülmelik hakkında onların düşüncelerini öğrenmek istemişti. Ancak İbn-i Şîrin ve Şa'bî yönetimden çekindiklerinden üstü kapalı cevaplar vermişlerdir. Hasan-1 Basrî ise Irak Valisine Yezid hakkındaki düşüncelerini açıkça söylemiş, Yezid'in uygulamalarını beğenmediğini dile getirmiştir. Ancak onun bu eleştirisine rağmen devlete isyan etmeyi de tasvip etmemiş, hatta fitne çıkmaması için isyanlara katılmama telkinleri olmuştur. ${ }^{90}$

Eğitim ve ilimler yönünden baktığımızda, sınırlı bilgilerimizden Yezid'in çocuğuna özel öğretmen tuttuğunu, Kur'an ve diğer ilimlerin öğretilmesini istediğini biliyoruz. ${ }^{91}$ Başka bir örnekten ${ }^{92}$ Yezid'in yine, Kur'anın çocuklara öğretilmesine önem verdiğini görüyoruz.

\section{SONUÇ}

Yezid b. Abdülmelik dönemiyle ilgili değerlendirmelerin büyük çoğunluğu aleyhinde görülürken, lehinde az da olsa görüşler vardır. Brockelmann gibi bazı medeniyet ve İslâm Tarihçileri Yezid hakkındaki olumsuz haberlerin, Emevîler dönemini kayda geçiren, Abbasîler tarafından kasıtlı olarak Emevîleri kötü gösterme çabasının bir sonucu olduğunu belirtmektedirler. Hatta Brockelmann bazı uygulamaları nedeniyle döneminin kısalı̆̆ına rağmen başarılı sayılabileceğini belirtmektedir. ${ }^{93}$ Çağdaş Arap İslâm Tarihçilerinden bazıları da Yezid'in hakkındaki olumsuz haberlerin abartılı olduğu üzerinde durmuşlardır ${ }^{94}$. Belirtilen Abbasî etkeninin haberlerde abartıya neden olabileceğini dikkate aldığımızı belirttikten sonra, bu görüşlerini kanaatimizce yeterli bilgiyle temellendirilemediğini de eklemek istiyoruz.

Sonuç olarak, diğer devlet başkanlarına göre kısa bir Halifelik dönemi olan Yezid dönemi, devletin derlenip toparlandığı Ömer b. Abdülaziz döneminden sonra yeniden iç karışıklıkların ortaya çıktığı, devletin zayıfladığı, Halifenin devlet işlerinden çok eğlenceyle meşgul olduğu bir dönemdir.

\footnotetext{
90 Belâzurî, Ensâb, VIII, 275; Mes'udî, Muruc, III, 201-202; İbni Asakir, XL, 376.

91 İbn Habib, Muhabber, 476.

92 İbni Zübeyr, Nesebû Kureyş, 114;İbni Hazm el-Endelusî, 83.

93 Brockelmann, 75.

94 Şelebi, Ahmed, ed-Devletü'l-Emevîyye, (7. Bask., Kahire 1984) 94-95; Akîl, Nebih, Tarihu Hilafet-i Beni Ümeyye, (Darü'l-Fikr, 3. Bask., Beyrut 1975), 299.
} 